\title{
Hubungan Kadar Feritin dengan Morbiditas pada Anak dengan Gizi Kurang
}

\author{
Endang Dewi Lestari, Rustam Siregar, Hari Wahyu Nugroho \\ Bagian Anak Fakultas Kedokteran Universitas Sebelas Maret, RSUD Dr Muwardi, Surakarta
}

Latar belakang. Kejadian infeksi dan inflamasi berhubungan dengan kekurangan zat besi, hal ini digambarkan dengan perubahan kadar feritin serum, zat besi serum, dan saturasi transferin pada saat fase akut.

Tujuan. Mengetahui hubungan antara morbiditas dengan kadar feritin serum pada anak dengan gizi kurang usia 7-9 tahun.

Metode. Pengambilan sampel penelitian dilakukan secara multi staging sampling. Kadar feritin diukur dengan menggunakan metode ELISA. Kejadian morbiditas infeksi saluran napas dan diketahui dengan pemeriksaan fisik oleh dokter infeksi saluran cerna. Data diolah dengan menggunakan SPSS 17.0. Hubungan antara morbiditas dengan kadar feritin serum dianalisis menggunakan regresi logistik.

Hasil. Penelitian dilakukan dengan 220 orang anak SD usia 7-9 tahun, terdiri dari 125 (52,27\%) lakilaki dan 105 (13,15\%) perempuan. Tigabelas (12 anak) mempunyai kadar feritin <12 $\mu \mathrm{g} / \mathrm{L}$. Di antara 79 $(86,81 \%)$ anak dengan kadar feritin $\geq 12 \mu \mathrm{g} / \mathrm{L}, 1$ (7,69\%) merupakan infeksi saluran cerna sedangkan 12 $(92,31 \%)$ menderita infeksi saluran nafas.

Kesimpulan. Peningkatan kadar feritin tidak berhubungan dengan kejadian morbiditas pada anak dengan gizi kurang. Sari Pediatri 2012;13(6):397-400.

Kata kunci: kadar feritin, morbiditas, gizi kurang

$\mathrm{K}$ ekurangan zat-zat mikronutrien masih merupakan masalah utama di sebagian besar negara yang sedang berkembang. terbesar kekurangan zat mikronupien di negaranegara yang sedang berkembang. Food and Agriculture

\footnotetext{
Alamat korespondensi:

Dr. Endang Dewi Lestari, Sp.A(K). Staf UPF Anak Bagian IKA FK-UNS/ RS Dr. Moewardi. Jl. Kol. Sutarto 132, Surakarta JATENG. Telp. (021) 666866
}

Organization (FAO) menyatakan lebih dari setengah anak-anak di negara berkembang kekurangan zat besi. ${ }^{1}$

Kekurangan zat besi akan mengakibatkan beberapa kelainan. Salah satu kelainan yang disebabkan oleh karena kekurangan zat besi ini adalah gangguan pada fungsi imunitas tubuh. ${ }^{1} \mathrm{Hal}$ ini dapat mempengaruhi imunitas tubuh baik imunitas humoral maupun imunitas seluler. Lebih lanjut kekurangan zat besi akan menyebabkan penurunan fungsi sel polimorfonuklear terutama neutrofil, penurunan jumlah dan fungsi limfosit $T$, penurunan aktivitas sel natural killer, serta penurunan aktivitas limfosit dan makrofag. ${ }^{2}$ 
Kejadian infeksi dan inflamasi berhubungan dengan kekurangan zat besi, hal ini digambarkan dengan perubahan kadar feritin serum, zat besi serum, dan saturasi transferin pada saat fase akut. ${ }^{3}$ Kadar serum feritin (SF) digunakan untuk menilai cadangan besi total dalam tubuh. Pada semua usia kadar feritin akan rendah $<12 \mu \mathrm{g} /$ liter apabila terjadi defisiensi besi. Kadar feritin serum dapat meningkat pada penyakit infeksi akut maupun kronis, seperti pada inflammatory bowel disease, ${ }^{4}$ infeksi virus atau bakteri, ${ }^{5}$ keracunan endotoksin tanpa penumpukan zat besi dan keadaan hiperferitinemia tersebut dapat menggambarkan derajat kerusakan hepatoseluler serta demam rematik. ${ }^{6}$ Peningkatan kadar serum feritin berhubungan juga dengan penyakit keganasan. ${ }^{7}$

Anak dengan status gizi kurang sering dikaitkan dengan infeksi dan defisiensi zat gizi mikro. ${ }^{8}$ Pada anak dengan status gizi kurang asupan makanan sebagai salah satu sumber mikronutrien kurang yang akan berakibat pada kondisi defisiensi. Kondisi defisiensi ini akan menyebabkan gangguan sistem kekebalan tubuh yang berakibat pada mudahnya terjadi infeksi pada anak dengan status gizi kurang. ${ }^{9}$ Penelitian kami bertujuan untuk melihat hubungan antara morbiditas dengan kadar feritin serum pada anak dengan gizi kurang usia 7-9 tahun.

\section{Metode}

Penelitian dengan desain potong lintang untuk menganalisis hubungan antara morbiditas dengan kadar feritin serum pada anak dengan gizi kurang yang dilakukan di sepuluh sekolah dasar (SD) di Surakarta pada Juli 2007. Pengambilan sampel penelitian dilakukan secara multi staging sampling. Randomisasi dilakukan untuk pemilihan SD di Surakarta. Pemilihan subjek penelitian dilakukan secara purposive sampling pada anak di sekolah dasar di Surakarta, yang dipilih berdasarkan kriteria inklusi adalah usia 7-9 tahun, gizi kurang (bb/u <P10, CDC 2000), tidak menderita penyakit ginjal, penyakit tiroid, talasemia, cacat bawaan secara klinis, memahami informasi penelitian secara tertulis dan menandatangani informed consent. Sedangkan anak dengan kadar hemoglobin kurang dari $8 \mathrm{gr} / \mathrm{dl}$ tidak diikutkan dalam penelitian. Kadar feritin diukur dengan menggunakan metode ELISA. Kejadian morbiditas diukur dengan melakukan anamnesis dan pemeriksaan fisik oleh dokter untuk mendiagnosis infeksi saluran napas dan infeksi saluran cerna. Data diolah dengan menggunakan SPSS 17.0. Hubungan antara morbiditas dengan kadar feritin serum diolah menggunakan analisis regresi logistik. Hasil signifikan apabila $\mathrm{p}<0,05$.

\section{Hasil}

Penelitian potong lintang dilakukan pada bulan Juli 2007. Didapatkan 220 anak usia 7-9 tahun yang memenuhi kriteria inklusi dan eksklusi penelitian. Orang tua dari setiap anak telah menyetujui untuk mengikuti penelitian. Tabel 1 menunjukkan karakteristik dasar subyek penelitian. Jumlah anak yang memenuhi kriteria inklusi penelitian adalah 220 anak. Usia 7-8 tahun sejumlah 107 anak dan usia 8-9 tahun sejumlah 113 anak. Terdapat 115 anak laki-laki $(52,27 \%)$ dan 105 anak perempuan $(47,73 \%)$.

Jumlah anak dengan kadar feritin $<12 \mu \mathrm{g} / \mathrm{L}$ yang menderita infeksi saluran napas 12 anak (13,19\%), sedangkan jumlah anak dengan kadar feritin $\geq 12$ $\mu \mathrm{g} / \mathrm{L}$ yang menderita infeksi saluran napas 79 anak $(86,81 \%)$. Jumlah anak dengan kadar feritin $<12$ $\mu \mathrm{g} / \mathrm{L}$ yang menderita infeksi saluran cerna satu anak (7,69\%), sedangkan jumlah anak dengan kadar feritin $\geq 12 \mu \mathrm{g} / \mathrm{L}$ yang menderita infeksi saluran cerna 12 anak (92,31\%). (Tabel 2.)

Anak dengan kadar feritin lebih dari $12 \mu \mathrm{g} / \mathrm{L}$ mempunyai Odds ratio 1,052 ( $p$ 0,9; CI 95\% 0,4802,306) terhadap kejadian morbiditas infeksi saluran napas dan infeksi saluran cerna.

Tabel 1. Karakteristik subyek penelitian

\begin{tabular}{lcc}
\hline Karakteristik & $\mathrm{n}=220$ & $\%$ \\
\hline Usia (tahun) & & \\
$\quad 7-8$ & 107 & 48,6 \\
$\quad 8-9$ & 113 & 51,4 \\
Jenis kelamin & & \\
$\quad$ Laki-laki & 115 & 52,27 \\
$\quad$ Perempuan & 105 & 47,73 \\
Kadar feritin ( $\mu \mathrm{g} / \mathrm{L})$ & & \\
$\quad<12$ & 29 & 13,2 \\
$\quad \geq 12$ & 191 & 86,8 \\
Morbiditas & & \\
$\quad$ Infeksi saluran napas & 91 & 41,4 \\
$\quad$ Infeksi saluran cerna & 13 & 5,9 \\
\hline$\quad$
\end{tabular}


Tabel 2. Distribusi morbiditas berdasarkan kadar feritin

\begin{tabular}{lcc}
\hline \multirow{2}{*}{ Morbiditas } & \multicolumn{2}{c}{ Kadar feritin $\mu \mathrm{g} / \mathrm{L}$} \\
\cline { 2 - 3 } & $<12$ & $\geq 12$ \\
\hline Infeksi saluran napas, n (\%) & $12(13,19)$ & $79(86,81)$ \\
Infeksi saluran pencernaan, n (\%) & $1(7,69)$ & $12(92,31)$ \\
\hline
\end{tabular}

\section{Pembahasan}

Besi merupakan mineral penting, dibutuhkan dalam berbagai proses metabolisme utama di dalam tubuh. Besi terutama berperan penting dalam pembentukan sel darah merah. ${ }^{10}$ Kekurangan besi berhubungan dengan tingkat penghasilan dan pola makan yang kurang tepat. Pola makan di negara berkembang yang mengandung fitat dalam jumlah yang tinggi, lebih banyak mengkonsumsi makanan berserat dan karbohidrat sedangkan asupan protein hewani kurang sehingga menurunkan penyerapan besi. Pendapatan penduduk yang rendah akan menyebabkan ketidakmampuan untuk membeli bahan makanan yang kaya kandungan besi. ${ }^{11,12}$

Penelitian uji potong lintang ini dilakukan terhadap 217 subyek anak sekolah dasar usia 7-9 tahun di daerah masyarakat ekonomi rendah di Solo. Penentuan sekolah dasar menggunakan data dari Dinas Pendidikan Nasional Surakarta, agar subyek yang didapat mempunyai karakteristik yang serupa seperti konsumsi makanan sehari-hari. Pemilihan subyek dengan status gizi kurang dan mengeksklusi anak dengan kadar hemoglobin kurang dari $8 \mathrm{~g} / \mathrm{dl}$ dimaksudkan untuk menyetarakan kadar besi pada subyek.

Zat besi dapat mempengaruhi respon imun sehingga akan berpengaruh juga terhadap terjadi infeksi pada seseorang. Proses atau respon imun spesifik membutuhkan zat besi dalam mengeliminasi mikroorganisme yang masuk ke dalam tubuh. Di lain pihak mikroorganisme juga membutuhkan zat besi ketika masuk ke dalam tubuh pejamu untuk proses multiplikasi. Oleh karena itu, kekurangan zat besi maupun kelebihan zat besi dapat berhubungan dengan kejadian infeksi dan perubahan sistim imun. Kekurangan zat besi berhubungan dengan pola diit dan tingkat penghasilan sedangkan kelebihan zat besi jarang sekali disebabkan oleh pola diit. Kelebihan zat besi berhubungan dengan gangguan metabolisme $\mathrm{Fe}$ seperti hemokromatosis. ${ }^{2,13}$ Makrofag merupakan sel imun yang berperan langsung dengan kadar besi dalam tubuh manusia. Hal tersebut berhubungan dengan fakta bahwa makrofag membutuhkan zat besi untuk memproduksi highly toxic hydroxyl radical, makrofag juga merupakan tempat penyimpanan besi yang utama pada saat terjadi proses inflamasi. Sitokin, radikal, serta protein fase akut yang dihasilkan oleh hati akan mempengaruhi homeostasis besi oleh makrofag dengan cara mengatur asupan dan keluaran besi sehingga akan memicu peningkatan retensi besi dalam makrofag pada saat terjadi inflamasi. Besi juga mengatur aktivitas sitokin, proliferasi, dan aktivitas limfosit sehingga diferensiasi dan aktivasi makrofag akan terpengaruh. ${ }^{14}$ Pada beberapa penelitian sebelumnya memperlihatkan hubungan antara peningkatan kadar feritin dengan kejadian infeksi. Peningkatan kadar feritin serum menggambarkan respons klinis terhadap mikroorganisme. ${ }^{15-18}$ Peningkatan kadar feritin serum terlihat pada kasus ensefalitis dan peningkatannya sebanding dengan peningkatan protein fase akut. ${ }^{19}$ Peningkatan kadar feritin serum juga terlihat pada kasus infeksi virus dengue. ${ }^{20}$ Penelitian oleh Beard $\mathrm{dkk}^{21}$ memperlihatkan hubungan yang signifikan antara peningkatan kadar feritin serum dengan kadar protein fase akut yaitu CRP dan AGP.

Pada penelitian kami memperlihatkan bahwa peningkatan kadar feritin tidak berhubungan dengan kejadian morbiditas pada anak dengan gizi kurang. Hal ini mungkin disebabkan pada penelitian kami tidak memperhitungkan variabel-variabel lain yang dapat mempengaruhi kadar feritin maupun kejadian morbiditas. Diperlukan penelitian lebih lanjut dengan analisa multivariat dan melihat penanda infeksi lainnya.

\section{Ucapan terima kasih}

Ucapan terima kasih kepada semua murid, guru, kepala sekolah yang telah mengorbankan waktu dan tenaga guna ikut terlibat dalam penelitian ini.Terima kasih kepada PT NESTLE yang telah membantu pelaksanaan penelitian. Kepada dr Leilani Lestarina, kami ucapkan terimakasih atas bantuan referensi.

\section{Daftar pustaka}

1. Dijkhuizen MA,Wieringa FT. Effects of iron and zinc supplementation in Indonesian infants on micronutrients status and growth. Am J Clin Nutr 2001;131:2860-5. 
2. Oppenheimer SJ. Iron and its relation to immunity and infectious disease. Am J Clin Nutr 2001;131:616S35 S.

3. Thomas C, Thomas L. Biochemical markers and hematologic indices in the diagnosis of functional iron deficiency. Clin Chem 2002;48:1066-76.

4. Bartels U, Peudeseu NS, Jarnum S. Iron absorption and serum feritin in chronic inflammatory bowel disease. Scand J Gastroenterol 1998;13:649-56.

5. Bingegard. 2008. Birgegard G, Hallgreu R, Killandir A. Serum ferritin during infection a longitudinal study. Scand J Haematol 2008;21:333-40.

6. Bentley DP, Williams P. Serum ferritin concentration as an index of storage iron in rheumatoid arthritis. J Clin Pathol 2002;27:786- 88.

7. Jacobs A, Miller F, Wormwood M. Ferritin in the serum of normal subjects and patients with iron deficiency and iron overload. Br Med J 2002;4:206-10.

8. Blossner M, de Onis M. Malnutrition quantifying health impact at national and local levels. WHO, 2005.

9. Niedzwiecki A, Rath M. Malnutrition: the leading cause of immmune deficiency disease worldwide. California: Dr Rath Research Institute;2005.

10. Ohls RK, Christensen RD. Development of the hematopoetic system. Dalam Behrman RE, Jenson $\mathrm{HB}$, Kliegman RM, penyunting. Nelson Textbook of Pediatrics. Edisi ke-17. Philadelpia: WB Saunder; 2004.h.1602-5.
11. Bhutta ZA. Iron and zink deficiency in children in developing countries. Brit Med J 2007;334:104-5.

12. Ho E. Metabolism and deficiency of zink. Diunduh dari www.ipi.oregonstate.edu. pada tanggal 2 April 2008.

13. Brock JH. Iron and immunity. Proceedings of the Nutrition Society 1986;45:305-15.

14. Theurl I, Fritsche G.. The macrophage: a cellular factory at the interphase between iron and immunity for the control of infections. BioMetals 2005;18:359-67.

15. Worwood M.. Ferritin. Blood Rev 1990;4: 259-69.

16. Griffith E. Iron and bacterial virulence: a brief overview. Biol Met 1991;4:7-13.

17. Wooldridge KG, Williams PH. Iron uptake mechanism of pathogenic bacteria. Microbiol Rev 1993;12:325-48.

18. Krol V, Cunha BA. Diagnostic significance of serum ferritin levels in infectious and non-infectious diseases. Infect Dis Pract 2003;27:199-200.

19. Cunha BA, Sachdev B, Canario D. Serum ferritin levels in West Nile encephalitis. Clin Microbiol Infect 2008.;10:184-6.

20. Chaiyaratana W, Chuansumrit A, Kalayanee A. Serum ferritin levels in children with dengue infection 2008;39:832-6.

21. Beard JL, Murray-Kolb LE, Rosales FJ. Interpretation of serum ferritin concentrations as indicators of totalbody iron stores in survey populations: the role of biomarkers for the acute phase respons. Am J Clin Nutr 2006;84:1498-505. 